\title{
Effect of Verbal Feedback in Twelve Weeks Handball Training on Self-Efficacy and Life Satisfaction
}

\author{
Turhan TOROS ${ }^{1}$ \\ 'School of Physical Education and Sports, Coaching Education Department, Mersin University, Turkey \\ Email:turhantoros@yahoo.com
}

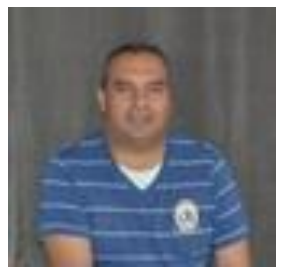

\begin{abstract}
The aim of this study was investigate the effect of verbal feedback on self-efficacy and life satisfaction. A total of 30 students as experimental group $(n=15$, mean age $=20.13 \pm 1.79)$ and control group $(n=15$, mean age $=20.57 \pm 1.62)$ with similar characteristics were included in the study. Self-efficacy scale that originally developed by Riggs et al. (1994) and adapted to Turkish population by Öcel (2002) and life satisfaction scale that originally developed by Diener et al. (1985) and adapted to Turkish population by Yetim (1991) were used. Shapiro-Wilk test was interpreted for normality in data analysis and it was observed that the distribution was not normal. And so Wilcoxon Marked Rank Test was used to determine the development and skills of the groups themselves. The Mann-Whitney $\mathrm{U}$ test was used to assess the development of the experimental and control group in terms of pretest and posttest scores. Cronbach Alpha reliability analysis was also performed for the scales used in the research. According to research findings, there was a statistically significant difference between test and control groups posttest, selfefficacy values and life satisfaction values $(\mathrm{p}<0.05)$. As a result, verbal feedback given to handball players over a twelve-week training period was found to have a positive effect on self-efficacy and life satisfaction.
\end{abstract}

Keywords: Handball, Feedback, Verbal feedback, Self-efficacy, Life satisfaction.

Citation | Turhan TOROS (2018). Effect of Verbal Feedback in Twelve Weeks Handball Training on Self-Efficacy and Life Satisfaction. Asian Journal of Education and Training, 4(1): 13-17.

\section{History:}

Received: 14 December 2017

Revised: 8 January 2018

Accepted: 12 January 2018

Published: 15 January 2018

Licensed: This work is licensed under a Creative Commons

Attribution 3.0 License (cc) E

Publisher:Asian Online Journal Publishing Group
Funding: This study received no specific financial support.

Competing Interests: The author declares that there are no conflicts of interests regarding the publication of this paper.

Transparency: The authors confirm that the manuscript is an honest, accurate, and transparent account of the study was reported; that no vital features of the study have been omitted; and that any discrepancies from the features of the study have been omit
study as planned have been explained.

study as planned have been explained.
Ethical: This study follows all ethical practices during writing.

\section{Contents}

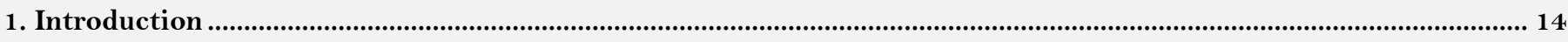

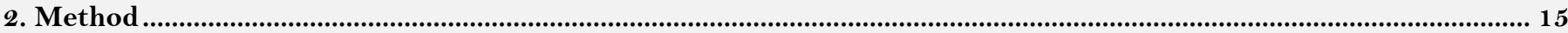

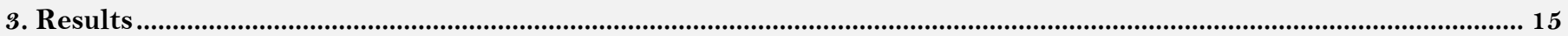

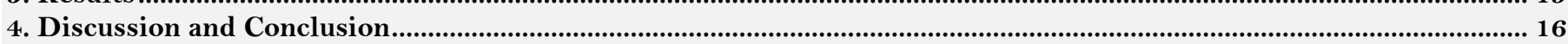

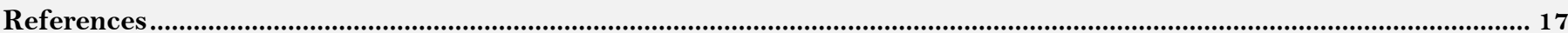




\section{Introduction}

The emphasis on the necessity of more objective investigations began to manifest itself in the early 1900 . It is based on learning that the active role of the past is to integrate with the situation in which day-to-day mankind is involved and to be able to adapt to the environment. The concept of learning leads people to behave in the future by reminding them of the past (Howe, 2001). Today, the need for learning of mankind is increasing (Ormrod, 2013; Sönmez, 2015). Learning can take place in many places and in many ways. People want to realize learning for the satisfaction of his inner feelings at any moment of his life, like showing themselves, learning money, being famous, being successful at work or just to be able to grow trees (Ormrod, 2013). Learning; is defined in many different forms but in general defined as continuous changes that are independent of the genetic characteristics of the person and have the process of being affected by the environment (Çelen, 1999; Fidan, 2012) the continuity of behavior as a result of repeats and experiences (Güney, 2014) or changes in the nervous system and therefore behavior with the person's experiences (Carlson, 2011). Therefore, the concept of motor learning can be explained in many ways. In addition to explaining the concept of motor learning in different ways, basically it is the capacity of the person in order to be able to make any move (Schmidt and Wrisberg, 2012).

Psychomotor behavior is all of the behaviors that allow the creation of a whole by combining the patterns and the coordinated operation of the muscles and minds that provide convenience to the individual at every moment of life. All of the patterns of psychomotor behavior, done correctly, quickly and in a series, are defined as skills (Fidan, 2012). In the process of learning a skill, the practitioner achieves his goal in a long program, which is complicated and able to carry out many learning tasks. Instructors use a variety of methods in the teaching of skills, trying to ensure that the practitioner learns to be successful. In this process, the instructor's most frequently used assistant is feedback given to the practitioner (Schmidt and Wrisberg, 2012). Feedback is defined as any sensory information given to a practicing person at the moment of act or at the end of the act. According to Schmidt and Lee (2014) feedback is information about the performance of a person during or after his or her performance. According to Singer (1975) feedback is information that one receives from sensory receptors about the end result of self-motion. In general, feedback is seen as a comparison between the applied skill and the target skill. Feedback during the learning phase is confronted in two ways.

The first is the internal feedback that can be continuously received from the senses without the need for external support by the practitioner as information coming from the proprioceptive senses, the muscles of the body sensation, and the joints or tendons (Magill, 2010). The other is that the information about the detail or quality of movement is provided from external sources of the individual when the internal feedback is not enough about the action of the practitioner, which is often used by instructors in the teaching phase. External devices such as verbal and non-verbal forms, chronometers, videos provide feedback, etc. provided by the coach or teacher as external feedback. External feedback is shown as an important teaching assistant in many studies (Zelaznik, 1996). External feedback is frequently used in two categories. Some of them give conclusions about the movement and the extent to which someone has reached or failed to achieve the goal of the skill he has applied; and the other is the feedback given by all instructors and coaches to the practitioner about the kinematics of movement such as speed, flow, etc. (Schmidt and Wrisberg, 2012). It is stated that external feedback is mostly given as verbal expressions and visual presentations (Coker, 2004). Verbal feedback varies according to the manner of administration. According to Mosston and Ashworth (2000) verbal feedback has been grouped into four main categories: delivery patterns, corrective expressions, value expressions, unbiased expressions and ambiguous expressions. In addition to the verbal feedback given to the individual, feedback can also be provided by using video recording to give information about the kinematics of the movement that the person has applied through the progress of the technology and the use of various instruments today, and to see how the movement can be more effective. It has been shown that external feedback is more effective for target movement in studies conducted both verbally and visually, rather than verbally or visually alone (Magill, 2010). Bandura (1997) explains self-efficacy with the definition of selfsufficient, which describes the sense of competence and competence that one can feel during his life. It is stated that people's feelings of skill and feelings that they can feel can be perceived internally and affect their behaviors. People who feel they can handle themselves are much more comfortable, successful, confident and consistent in the things they face in their lives, while those with low self-esteem are seen to be helpless and therefore unhappy in their negative situations. They think that there are no energies or powers that can produce solutions to these negative situations that affect them. If they are in a negative situation, if they get bad results, they seem to have given up on what they have already done. Bandura argues that person behavior change is not through reinforcements. At the same time, learning is described as monitoring other people and trying to imitate behavior as a model by taking them as a model (Schultz, 2007). It is described as a skill that the person who learns a skill will be able to perform or a thought about how well he can do the action. An athlete who runs a short distance may have a high belief in himself at $100 \mathrm{~m}$, but the same athlete may not be able to see it in a marathon run. A student who is good at social classes may not see enough competence in numerical courses in his / her own (Stodolsky et al., 1991). A person with a high self-efficacy in jumping on a trampoline in a swimming class may not be self-efficient to go underwater from one side to the other (Ormrod, 2013).

Life satisfaction is expressed as a result of people gazing at the difference between their anticipated lives and their existing lives by comparing their current lives with their expectation and being able to see their motivation at the top level and to be well with the life satisfaction (Özer and Karabulut, 2003). It is the evaluation of the information that exists in relation to the life of the person (Diener et al., 1985). It is the emotional state that is evidenced by the consistency of the situation between the person's expectations and life (Mutlu, 2012). It is life satisfaction that humans compare life situations they live in with life expectancies, and they are close to the expectations of their lives (Turan, 2013). Flanagan (1978) stated that factors affecting quality of life are physical and material wellbeing, human relations, social citizenship activities, personal development and satisfaction with their potential and recreation. It is presented through various researches that it is possible for the athlete to meet life expectancy by accessing the life satisfaction variable, the complicated and difficult movement that the athlete has just learned, and the achievement of the target behavior in the application result. Sports psychology is a 
versatile field that includes learning skills, cognitive and affective domains. For this reason, skills must be learned in the most accurate way in the learning of skills.

In this research, the effect of verbal feedback on life satisfaction and self-efficacy was investigated, which is believed to increase the handball qualities of athletes and to have a great share in the learning of the skills that are subject to many researches all over the world. The purpose of this study was to investigate the effect of verbal feedback, self-efficacy and life satisfaction on twelve-week training.

\section{Method}

\subsection{Research Group}

Thirty male volunteers participated in the survey, which had never played handball and did not know any handball games. 15 students in 12-week training with verbal feedback in the experimental group and 15 students in 12 -week training with no verbal feedback were included in the control group. The mean age of the research group; for the experimental group (20.13 \pm 1.79$)$ and for the control group (20.57 \pm 1.62$)$. Experimental group participated handball training for 12 weeks, two days a week and 60 minutes per day. Verbal feedback was given to experimental group during training. Control group also participated handball training for 12 weeks, two days a week and 60 minutes per day with no verbal feedback. Self-efficacy and life satisfaction scales were applied as pretest and after 12 weeks scales were applied again as posttest and the effects of verbal feedback were examined.

\subsection{Process}

The points to be noted in the practice of the handball training exercises explained by the trainer to the experimental group with verbal feedback. The number of repetitions and the duration of the training were the same as the control group. Athletes were given at most 2 verbal feedbacks in the $4^{\text {th }}$ practice after every $3^{\text {rd }}$ set. In every training day, all athletes were given equal 15 verbal feedbacks. Verbal feedback was determined according to handball training drills.

\subsection{Data Collection}

\subsubsection{Self-Efficacy Scale}

In this study, Self-Efficacy Scale was used that developed by Riggs et al. (1994). The Self-Efficacy Scale was developed to measure the beliefs in their capacities of individuals. Adapting the scale to Turkish developed by Öcel (2002) and the scale is composed of 10 items in total. The scale is evaluated on the $5^{\text {th }}$ Likert Type and a single qualification score is obtained by adding the numerical values marked for the items. The lowest score that can be taken from the scale is 10 , the highest score is 50 and the high score is considered as a strong self-efficacy belief. As calculated by Riggs et al. (1994) and reported by other researchers, the internal consistency coefficient is .80. On the other hand, the internal consistency coefficient of the scale is calculated as .61. Although this value is not high as expected, it is found to be sufficient level (Öcel, 2002). Internal consistency in the study was calculated as .92.

\subsubsection{Life Satisfaction Scale}

The life satisfaction scale was formed in the same way in 5 expressions. Participants were asked to report their level of participation in each item according to a 7-point evaluation system ( 1 totally disagree-7 totally agree). Test-retest reliability of the scale was found to be 0.58 in the four-year period and 0.58 in the six-year period (Yetim, 1991). The Turkish version of the scale developed by Diener et al. (1985) was made by Yetim (1991). The internal consistency of the scale in Turkey is .78 (Yetim, 1991) and the internal consistency in this study is calculated as .70.

\subsection{Data Analysis}

Descriptive statistics were used to determine the age and number of participants in the study groups. If the group size is less than 50, Shapiro-Wilk, if it is greater than 50, Kolmogorov-Smirnov tests are two tests used to determine normality. The distribution is normal in the case of $\mathrm{p}>.05$ (Aron and Aron, 2003). The Shapiro-Wilk test was interpreted for normality. For the experimental group the distribution did not show a normality values below $\mathrm{p}<0.05$ in all variables. The distribution did not show normality in all variables for bot experimental and control groups. The Wilcoxon Marked Rank Test was used to determine the development and skills of the groups themselves. The Mann-Whitney U test was used to assess the development of the experimental and control groups in terms of pre-test and post-test scores. Cronbach Alpha reliability analysis was also performed for the scales used in the research. Significance level taken as p<.05. SPSS-22 statistical package program was used in the analysis of the data obtained in the research.

\section{Results}

Table-1. Pre-test and Post-Test Self-Efficacy Findings of Experimental Group according to Wilcoxon Signed Rank Test.

\begin{tabular}{l|l|l|lll}
\hline $\begin{array}{l}\text { Experimental Group Pretest-Posttest Self- } \\
\text { Efficacy }\end{array}$ & $\mathbf{n}$ & Rank Average & Rank Sum & Z & P \\
\hline Negative Rank & $1^{\text {a }}$ & 5,00 & 5,00 & 0,941 & 0,321 \\
\hline Positive Rank & $5^{\text {b }}$ & 2,00 & 13,00 & \\
\hline Equal & $9^{\text {c }}$ & & & & \\
\hline
\end{tabular}

Table 1 shows that there was no statistically significant difference between pre-test post-test self-efficacy values of the experimental group $(Z=0,941 \mathrm{p}>.05)$. 
Table-2. Pre-test and Post-Test Self-Efficacy Findings of Control Group according to Wilcoxon Signed Rank Test.

\begin{tabular}{ll|l|l|lll}
\hline $\begin{array}{l}\text { Control Group Pretest-Posttest Self- } \\
\text { Efficacy }\end{array}$ & $\mathbf{n}$ & Rank Average & Rank Sum & Z & P \\
\hline Negative Rank & $6^{\mathrm{a}}$ & 7.44 & 48.5 & 1.500 & 0,104 \\
\hline Positive Rank & $7^{\mathrm{b}}$ & 11.45 & 124.5 & & \\
\hline Equal & $2^{\mathrm{c}}$ & & & & \\
\hline
\end{tabular}

Table 2 shows that there was no statistically significant difference between pre-test post-test self-efficacy values of the control group $(Z=1,500 \mathrm{p}>.05)$.

Table-3. Pre-test and Post-Test Life Satisfaction Findings of Experimental Group according to Wilcoxon Signed Rank Test.

\begin{tabular}{l|l|l|lcc}
\hline $\begin{array}{l}\text { Experimental Group Pretest- } \\
\text { Posttest Life Satisfaction }\end{array}$ & $\mathbf{n}$ & Rank Average & Rank Sum & Z & P \\
\hline Negative Rank & $1^{\mathrm{a}}$ & 4,00 & 6,00 & 0,734 \\
\hline Positive Rank & $4^{\mathrm{b}}$ & 3,50 & 9,00 & \\
\hline Equal & $10^{\mathrm{c}}$ & & & & \\
\hline
\end{tabular}

Table 3 shows that there was no statistically significant difference between pre-test post-test life satisfaction values of the experimental group $(Z=0,734 \mathrm{p}>.05)$.

Table-4. Pre-test and Post-Test Life Satisfaction Findings of Control Group according to Wilcoxon Signed Rank Test.

\begin{tabular}{l|l|l|lcl}
\hline $\begin{array}{l}\text { Control Group Pretest-Posttest Life } \\
\text { Satisfaction }\end{array}$ & $\mathbf{n}$ & Rank Average & Sum of Rank & Z & P \\
\hline Negative Rank & $4^{\mathrm{a}}$ & 8.92 & 31.68 & 0,958 & 0,354 \\
\hline Positive Rank & $7^{\mathrm{b}}$ & 7.67 & 66.50 & & \\
\hline Equal & $4^{\mathrm{c}}$ & & & & \\
\hline
\end{tabular}

Table 4 shows that there was no statistically significant difference between pre-test post-test life satisfaction values of the control group $(Z=0,958 \mathrm{p}>.05)$.

Table-5. Mann-Whitney U Test Results for the Comparison of the Post Test Self-Efficacy Averages of the Experimental and Control Groups.

\begin{tabular}{l|l|l|l|l|l}
\hline Group & $\mathbf{n}$ & Rank Average & Sum of Rank & U & p \\
\hline Experimental & 15 & 19,32 & 486,65 & \multirow{2}{*}{118,500} & \multirow{2}{*}{0,039} \\
\hline Control & 15 & 11,60 & 330,70 & & \\
\hline
\end{tabular}

According to the results of Mann Whitney U, there was significant difference between the handball players' self-efficacy means $(\mathrm{U}=118,5, \mathrm{p}<.05)$. When rank order is taken into consideration, it is understood that handball players with verbal feedback have higher self-efficacy averages than other group.

Table-6. Mann-Whitney U Test Findings for Comparison of Life Satisfaction Averages of the Experimental and Control Group

\begin{tabular}{l|l|l|l|l|l}
\hline Group & n & Rank Average & Sum of Rank & U & p \\
\hline Experimental & 15 & 19,27 & 528 & \multirow{2}{*}{104} & \multirow{2}{*}{0,008} \\
\hline Control & 15 & 9,73 & 311 & & \\
\hline
\end{tabular}

According to the results of Mann Whitney U, there was significant difference between the handball players' life satisfaction means $(\mathrm{U}=104, \mathrm{p}<.05)$. When rank order is taken into consideration, it is understood that handball players with verbal feedback have higher life satisfaction averages than other group.

\section{Discussion and Conclusion}

In comparison of the self-efficacy scores of the control and experimental groups, it was found that there was a significant difference between the self-efficacy mean scores of the handball players with verbal feedback and the handball players without verbal feedback in the result of twelve-week training. When the rank average is taken into consideration, it is seen that the rank average of the handball players in the experimental group is higher than the control group. According to these findings, in the eight-week training with verbal feedback, handball players are believed to be able to achieve success and to increase their belief in doing the same skills in the future.

Miçooğulları et al. (2015) investigated the exercise self-efficacy and exercise viewpoint of young adult individuals according to the gender and exercise behavior change stages. They found that individuals who regularly participate in exercises felt more efficient and they perceived exercise as a process of success. The findings of their study are similar to our study.

Comparing the mean scores of life satisfaction of the control and experimental groups, it was found that there was a significant difference between the scores of handball players with verbal feedback and others scores of twelve weeks of training. When the order average is taken into consideration, it is seen that the row average of the handballs in the experimental group is higher than the control group. According to these findings, verbal feedback during the twelve-week training period is believed to be beneficial when handball players are entrusted by professional coaches and enjoy the environment they are in, and that they can achieve success from the training they have applied.

In the study of Toros (2001) studying the effect of goal orientations on elite and non-elite male basketball players, goal orientation and motivational climate, difficulty level characteristics on life satisfaction, individuals 
who are satisfied with life moderately satisfy this modesty, and that they prefer to have a sense of superiority. These findings are similar to our study.

\section{References}

Aron, A. and E.N. Aron, 2003. Statistics for psychology. 3rd Edn., Upper Saddle River, New Jersey: Prentice Hall.

Bandura, A., 1997. Self-efficacy: The exercise of control. New York: Macmillan.

Carlson, N.R., 2011. Physiological psychology. (In Turkish) Ankara: Nobel Akademik Yayıncılık.

Çelen, N., 1999. Learning psychology theories. Ankara: Imge Bookstore..

Coker, C.A., 2004. Motor learning and control for practitioners. McGraw-Hill Humanities/Social Sciences/Languages.

Diener, E.D., R.A. Emmons, R.J. Larsen and S. Griffin, 1985. The satisfaction with life scale. Journal of Personality Assessment, 49(1): 71-75. View at Google Scholar

Fidan, N., 2012. Learning and teaching in school. Ankara: Pegem Akademi.

Flanagan, J.C., 1978. A research approach to improving our quality of life. American Psychologist, 33(2): 138-147. View at Google Scholar | View at Publisher

Güney, S., 2014. Behavioral sciences. (In Turkish) Ankara: Nobel Academic Publishing.

Howe, M.J., 2001. Learning psychology (E. Kılıç, Trans.). İstanbul: Alfa Publishing.

Magill, R.A., 2010. Motor learning and control: Concepts and applications. Boston: McGraw-Hill, 111.

Miçooğulları, B.O., C. Cengiz, F.H. Aşçı and S. Kirazcı, 2015. Examinations of young adults' exercise self-efficacy and decisional balance with regard to gender and exercise stage of change. Hacettepe Journal of Sport Sciences, 21(2): 49-59. View at Google Scholar

Mosston, M. and S. Ashworth, 2000. Physical education education, (E. Tüzemen, Trans.). Ankara: The publishing house.

Mutlu, Z., 2012. Investigation of the relationship between the factors that affect life satisfaction and social support among elderly. Unpublished Master Thesis. Ankara: Gazi University, Educational Sciences Institute.

Öcel, H., 2002. Relationships between collective competence self-efficacy and fainting and success perception and expectation in team sports players. Ankara: Unpublished Master Thesis. Hacettepe University Social Sciences Institute.

Ormrod, E.J., 2013. Learning psychology (M. Baloglu, Trans.). Ankara: Nobel Academic Publishing.

Özer, M. and Ö.Ö. Karabulut, 2003. Satisfaction of life in elderly individuals. Geriatri, 6(2): 72-74. View at Google Scholar

Riggs, M.L., J. Warka, B. Babasa, R. Betancourt and S. Hooker, 1994. Development and validation of self-efficacy and outcome expectancy scales for job-related applications. Educational and Psychological Measurement, 54(3): 793-802. View at Google Scholar $\mid$ View at Publisher

Schmidt, R.A. and T.D. Lee, 2014. Motor learning and performance. From principles to application. Champaign. IL: Human Kinetics.

Schmidt, R.A. and C.A. Wrisberg, 2012. Motor learning and performance (Z. Koruç, N. Arsan, S. Kağan, Trans.). Ankara: Anı Publishing.

Schultz, D.S., 2007. History of modern psychology. (Y. Aslay, Trans.). İstanbul: Kaknüs Publishing.

Singer, R.N., 1975. Motor learning and human performance: An application to physical education skills. Macmillan.

Sönmez, V., 2015. Teachers handbook in program development. Ankara: Anı Publishing.

Stodolsky, S.S., S. Salk and B. Glaessner, 1991. Student views about learning math and social studies. American Educational Research Journal, 28(1): 89-1 16. View at Google Scholar | View at Publisher

Toros, T., 2001. Effects of goal orientation, motivational climate, the degree of difficulty and properties of goal to life satisfaction in elite and non-elite male basketball players. Unpublished Master Thesis. Mersin: Mersin University Health Sciences Institute.

Turan, M.E., 2013. The relationship between career and talent development self-efficacy with metacognitive awareness, life satisfaction and perceived friend social support. Master Thesis. Sakarya University, Educational Sciences Institute.

Yetim, Ü., 1991. Life satisfaction in terms of organization and pattern of personal projects. (In Turkish). Doctoral Thesis. İzmir: Ege University, Social Sciences Institute.

Zelaznik, H.N., 1996. Advances in motor learning and control. Champaign: Human Kinetics. 